\title{
ARTIGOS
}

\section{SOUTH AMERICAN RATTLESNAKE VENOM: ITS HEMOLYTIC POWER}

\author{
Édimo Garcia de Lima ${ }^{1}$, Paulo Inácio da Costa ${ }^{1}$ and Carlos Julio Laure ${ }^{2}$
}

\begin{abstract}
The hemolytic power of rattlesnake venom (Crotalus durissus terrificus) was studied $A$ high percentage of sample with negative hemolytic power was detected when sheep red blood cells were used. A large number of venoms with hemolytic power, though with a low hemolysis percentage, were detected when liquid, recently extracted venom was used. When crystallized venom was used under the same experimental conditions, a higher percentage of positivity for hemolysis was obtained. When the results obtained on agar plates were compared to those obtained in test tubes, a large number of animals with a higher percentage of hemolysis were detected, though this value was not proportional to the number of animals showing positive plate hemolysis. When the hemolytic power of these venoms was tested on human red blood cells, a large percentage of animals with venoms having a low hemolytic power was also detected. Hemolytic power was much greater when human red blood cells were tested with crystallized venom. The preparation of red blood cells also had an important effect and the use of red blood cells from defibrinated blood is recommended. We conclude that rattlesnake venom has hemolytic power that increases when the venom is crystallized. Red blood cells should be properly prepared for the lysis reactions. We suggest that the lytic power of the venom is related to venom concentration and to the purity of its fractions.
\end{abstract}

Key-words: Rattlesnake venom. Hemolytic power.

Studies have demonstrated the proteolytic properties of snake venom 45781215 . A proteinase present in the venom of a snake of the genus Crotalus has been found to be able to induce this phenomenon in the vascular system of mice injected intramuscularly with a subletal dose, the effect being dose-dependent ${ }^{13}$. Cellular lesions and even membrane rupture were detected by electron microscopy. Some investigators 611 demonstrated that some venoms can increase erythrocyte membrane permeability and can also act on leucocytes.

Because of its enzymatic action on cell membrane phospholipids, phospholipase can alter membrane permeability, causing indirect hemolysis by the formation of lysophosphatides. Rattlesnake venom has been shown to have a hemolytic action on the red blood cells of man and other animals ${ }^{9} 14$.

1. Department of Parasitology, Microbiology and Immunology.

2. Department of Biochemistry.

Correspondence to: Dr. Edimo Garcia de Lima, Faculty of medicine of Ribeirão Preto/USP. 14049 Ribeiraao Preto, SP. Brasil.

Recebido para publicação em 15/06/89.
The objective of the present study was to demonstrate the hemolytic power "in vitro" induced by whole rattlesnake venom, using freshly collected and crystallized venom and sheep and human red blood cells.

\section{MATERIAL AND METHODS}

The material used in the present study consisted of liquid venom, i.e. venom immediately extracted from the animal, and dry, crystallized but not lyophylised venom, venom fractions and sheep and human red blood cells diluted in incomplete phosphate buffered solution (PBSI): $\left(\mathrm{NaCl}, 41.0 \mathrm{~g} ; \mathrm{KH}_{2} \mathrm{PO}_{4}, 1.0 \mathrm{~g}\right.$; $\mathrm{Na}_{2} \mathrm{HPO}_{4} ; 12 \mathrm{H}_{2} \mathrm{O}, 1.0 \mathrm{~g} ; \mathrm{KCl}, 1.0 \mathrm{~g} ; \mathrm{H}_{2} \mathrm{O}, 5000 \mathrm{ml}$ ), pH 7.4.

Venom was extracted from Crotalus durissus terrificus snakes by the technique of Garcia Lima and Laure ${ }^{3}$. The venom was immediately placed on sterilesed blood-agar (rabbit blood) plates, which were incubated for 24 hours at $37^{\circ} \mathrm{C}$. Hemolysis was read with EEL colorimeter with a $540 \mathrm{~nm}$ filter. The amount of liquid venom used was $\mu$, corresponding to 1.9 $\mathrm{mg}$ of crystallized venom.

The same venom volume was mixed with $0.2 \mathrm{ml}$ of a $2.5 \%$ sheep red blood cell suspension in PBSI. 
Lima EG, Costa PI, Laure CJ. South American rattlesnake venom: its hemolytic power. Revista da Sociedade Brasileira de Medicina Tropical 22: 171-175, Out-Dez, 1989.

The mixture was incubated for 24 hours and hemolysis readings were taken at 30 minute intervals. The remaining part of the extracted venom was allowed to $\mathrm{dry}$ at room temperature $\left(22^{\circ} \mathrm{C}\right)$ and weighed. A 1.0 $\mathrm{mg}$ amount was weighed for each venom sample from each snake and placed in $0.1 \mathrm{ml}$ PBSI containing 0.2 $\mathrm{ml} 2.5 \%$ sheep red blood cells in PBSI. The mixtures were incubated for 4 hours at $37^{\circ} \mathrm{C}$ and PBSI was added to a final volume of $1.0 \mathrm{ml}$. Hemolysis readings were taken after 12 and 24 hours. Venom fractions were obtained by the methods of Laure ${ }^{10}$ Gabilan $^{2}$ and Conti ${ }^{1}$. Controls were made in PBSI.

\section{RESULTS}

\section{Sheep red blood cells}

Venom samples of 27 animals held in captivity under controlled temperature, humidity and feeding conditions were examined. Venoms were extracted under asepsis to avoid contamination by the operator or the environment and immediately added to a red blood cell suspension. The material $(10 \mu \mathrm{l}$ samples of liquid venom) was incubated at $37^{\circ} \mathrm{C}$ and hemolysis read. The results are shown in Table 1. extracted whole venom and incubated for 24 hours at $37^{\circ} \mathrm{C}$. Hemolysis results are reported in Table 4.

Hemolysis of human red blood cells was also studied using crystallized venom which had been extracted 7 days before use (Table 4 and Figure 1).

A study to determine the effect of the red blood cell preparation, i.e. red blood cells washed with PBSI but preserved with heparin, or red blood cells simply obtained from defibrinated sheep blood is shown in Table 5 and Figure 2.

The results of the hemolytic power of venom fractions are shown in Table 6.

\section{DISCUSSION AND CONCLUSIONS}

Few studies have been carried out on the hemolytic power of rattlesnake venom (Crotalus durissus terrificus), but the subject has been extensively discussed.

Habermann ${ }^{6}$ and $O^{\prime}$ Connor and Peck ${ }^{11}$ reported that some venoms have the ability to increase the permeability of red blood cell and leucocyte membranes. It is known that phospholipase, as an enzyme, has the ability to induce hemolysis in an indirect manner.

Table 1 Hemolysis of sheep red blood cells induced by liquid or crystallized venom in test tube reactions.

\begin{tabular}{|c|c|c|c|}
\hline \multicolumn{2}{|c|}{ Percentage of animals* } & \multicolumn{2}{|c|}{ \% Hemolysis intervals } \\
\hline Liquid venom & Crystallized & Liquid venom & Crystallized \\
\hline 68.82 & 10.65 & $0-5$ & $0-5$ \\
\hline 8.96 & 52.78 & $10-15$ & $10-15$ \\
\hline 8.24 & 19.91 & $20-25$ & $20-25$ \\
\hline 8.24 & 11.11 & $30-35$ & $30-35$ \\
\hline 4.30 & 5.09 & $40-45$ & $40-45$ \\
\hline 0.72 & 0.46 & $50-60$ & $50--$ \\
\hline 0.72 & - & $-\quad-70$ & $-\quad-\quad-$ \\
\hline
\end{tabular}

* 279 animals used by liquid venom $(10 \mu \mathrm{l})$ and 216 animals by crystallized venom $(1.9 \mathrm{mg})$.

The controls were made in PBSI and the results show negative hemolysis.

Hemolysis obtained with crystallized venom $(1.0 \mathrm{mg}$ whole venom with $0.5 \mathrm{ml}$ diluted red blood cells) was a! $s$ studied.

When plate hemolysis was compared with tube hemolysis the data shown in Table 2 were obtained.

The results obtained with plate hemolysis and tube hemolysis were related to the presence of crotamine in venom, determined by paper electrophoresis, and are shown in Table 3.

\section{Human red blood cells}

Human red blood cells were washed and diluted to $5 \%$ at the proportion of $0.5 \mathrm{ml}$ per $4 \mu \mathrm{l}$ recently
The venoms studied here were obtained from animals held in captivity using a technique ${ }^{3}$ that permits the extraction of venom free from environmental contamination. Whole venom and red blood cell mixtures, separate or incorporated into agar, were incubated at $37^{\circ}$ for 24 hours for hemolysis determination. When the venom was used in natura, i.e. still in the liquid state, with sheep red blood cells, the number of negative hemolyses $(68.82 \%)$ was much higher than the number of positive hemolyses $(3.18 \%)$. The positive readings, however, were evident and distributed over a percentage of 10 to $60 \%$. Only the venom of two animals showed a percentage of hemolysis higher than this limit (70\%). These results led us to 
Lima EG, Costa PI, Laure CJ. South American rattlesnake venom: its hemolytic power. Revista da Sociedade Brasileira de Medicina Tropical 22: 171-175, Out-Dez, 1989.

Table 2 - Relationship between plate hemolysis and percentage of hemolysis in test tubes.

\begin{tabular}{cc}
\hline $\begin{array}{c}\text { Plates } \\
\text { (Positive hemolysis) } \\
\text { n. of venom samples }\end{array}$ & $\begin{array}{c}\text { Test tubes } \\
\text { Percentage of } \\
\text { hemolysis }\end{array}$ \\
\hline 2 & 0 \\
21 & 5 \\
3 & 10 \\
2 & 15 \\
1 & 20 \\
4 & 25 \\
2 & 30 \\
2 & 40 \\
1 & 45 \\
1 & 50 \\
\hline
\end{tabular}

believe that the active hemolytic portion of the venom is diluted in liquid, recently extracted venom. However, even though hemolysis rates were low, hemolysis was shown to be present in the venoms of more than $40 \%$ of the animals examined (Table 1 ).

When the venoms were allowed to crystallize the incidence of negative hemolyses was low $(10.65 \%)$, but the percentage of animals whose venoms showed hemolytic ability increased to $89.35 \%$. These results indicate that crystallized venom can cause hemolysis of a greater concentration of its fractions into a smaller portion (Table 1).

Hemolysis was obtained also when red blood cells were incorporated into nobel agar (Table 2). These were the results that called our attention to the hemolytic power of rattlesnake venom. When the hemolytic power of the venom on a plate was compared to that detected in tubes, we observed that the

Table 3 - Relationship between plate and test tube hemolysis and the presence of crotamine.

\begin{tabular}{cccccc}
\hline $\begin{array}{c}\text { No of } \\
\text { animals }\end{array}$ & Positive & Negative & Present & Absent & Test tube hemolysis \\
& & & & & Mean \% \\
\hline 28 & - & 28 & 3 & 25 & 12 \\
74 & 74 & - & 11 & 63 & 14 \\
\hline
\end{tabular}

Table 4 - Human red blood cell hemolysis induced by whole and crystallized venom.

\begin{tabular}{ccccc}
\hline $\begin{array}{l}\text { Hemolysis } \\
\text { (intervals) }\end{array}$ & \multicolumn{4}{c}{ Incidence (no of animals) } \\
\cline { 2 - 5 } & Whole venom & $\%$ & Crystallized & $\%$ \\
\hline $5-10$ & 89 & 89 & 53 & 53 \\
$15-20$ & 2 & 2 & 18 & 18 \\
$25-30$ & 1 & 1 & 0 & 0 \\
$35-100$ & 8 & 8 & 29 & 29 \\
\hline
\end{tabular}

Table 5 - Action of whole rattlesnake venom on defibrinated sheep red blood cells.

\begin{tabular}{rcc}
\hline $\begin{array}{l}\text { Hemolysis } \\
\text { (intervals) }\end{array}$ & \multicolumn{2}{c}{ Incidence (n. of animals) } \\
\cline { 2 - 3 } & $\begin{array}{c}\text { Erythrocytes from } \\
\text { non-defibrinated blood }\end{array}$ & $\begin{array}{c}\text { Erythrocytes from } \\
\text { defibrinated blood }\end{array}$ \\
\hline $5-10$ & 89 & 69 \\
$15-20$ & 2 & 3 \\
$25-30$ & 1 & 27 \\
$35-100$ & 8 & \\
\hline
\end{tabular}


Lima EG, Costa PI, Laure CJ. South American rattlesnake venom: its hemolytic power. Revista da Sociedade Brasileira de Medicina Tropical 22: 171-175, Out-Dez, 1989.

Table 6 - Percentual hemolytic power of rattlesnake venom fractions.

After 2 hours

Venom fractions

Sheep red
Sheep red
blood cells

\begin{abstract}
Human red blood cells
\end{abstract}

After 4 hours

\begin{tabular}{cc}
\hline $\begin{array}{c}\text { Sheep red } \\
\text { blood cells }\end{array}$ & $\begin{array}{c}\text { Human red } \\
\text { blood cells }\end{array}$ \\
\hline 30 & 90 \\
10 & 65 \\
10 & 90 \\
30 & 40 \\
10 & 50 \\
\hline
\end{tabular}

venoms of some animals had no hemolytic power on agar plates but did show hemolytic power on material in tubes, and vice versa (Table 2). When the results of hemolysis on plates were correlated with the presence of crotamine in the venoms, crotamine was found not to have any interfering effect on hemolysis either on agar plates or in tubes (Table 3).

When the hemolytic power of whole venom on human red blood cells was studied, the following results were obtained: a high percentage of low hemolysis (89\%), a medium percentage of hemolysis (15 to $30 \%$ ) in a small number of venoms, though the results were statistically very clear, and also a high percentage of hemolysis $(35-100 \%)$ in a small number of venoms (8\%). These results show that the number of animals whose venoms had a hemolytic effect was small, though the effect was quite evident. This may also have occurred because of the concentration of hemolytic power in each venom (Table 4 and Figure 1).

When the hemolytic power of crystallized venom was tested on human red blood cells (Table 4 and Figure 1), we also detected a large number of venoms

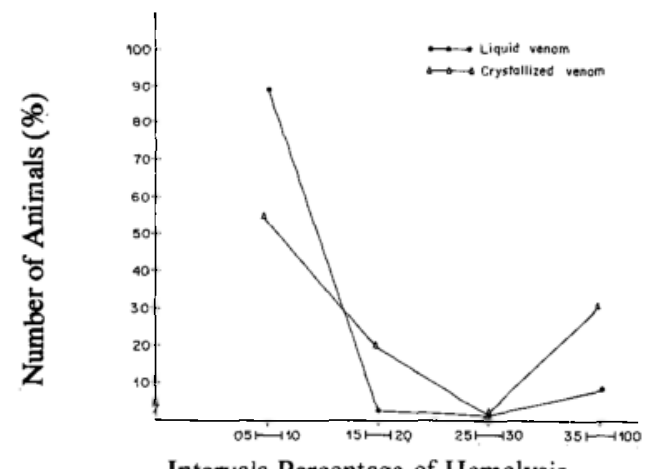

Intervals Percentage of Hemolysis

Figure 1 - Hemolysis of human red blood cells induced by freshly extracted rattlesnake liquid venom $(\mathrm{n}=279) 10 \mu \mathrm{l}$ and crystallized venom $(\mathrm{n}=216)$ $1.9 \mathrm{mg}$.
(53.00\%) with low hemolysis rates, 18 animals whose venoms had medium hemolytic power (15-30\%) and a larger number of venoms (29.00\%) with high hemolytic power (35-100\%), showing high statistical significance. This indicates that the hemolytic power is more concentrated in crystallized venoms (Table 4 and Figure 1).

When hemolysis rates were studied as a function of the manner in which blood was obtained, red blood cells from defibrinated blood were hemolysed at a lower rate than red blood cells from blood collected with heparin at all intervals (Table 5 and Figure 2). When the hemolytic power of whole venom fractions was tested (Table 6), the concentrated fractions showed individual hemolytic power varying from fraction to fraction. Human red blood cells were found to be more susceptible to the action of whole venom and venom fractions than sheep red blood cells.

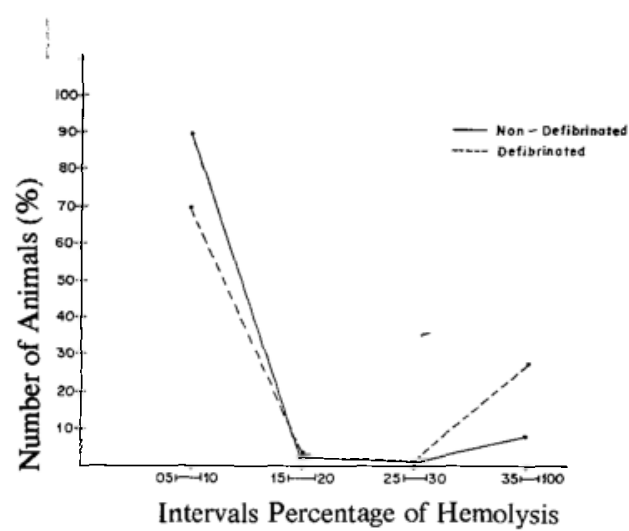

Figure 2 - Action of whole rattlesnake venom $(n=279)$ on defibrinated and non-defibrinated sheep red blood cells.

We conclude that, under the conditions employed in the present study, rattlesnake venom has hemolytic power which increases when the venom is crystallized. The red blood cells should be properly prepared for the lysis reactions. We suggest that the 
power of the venom is related to venom concentration and to the purity of its fractions.

\section{RESUMO}

Foi estudado o poder hemolitico do veneno da cascavel (Crotalus durissus terrificus). Encontrou-se grande número de suas fraçōes sem capacidade de hemolisar eritrócitos de carneiro. O veneno "in natura", recentemente extraido, e em estado líquido tem pouca atividade lítica. A cristalização do veneno aumenta sua concentração e poder lítico. Os resultados de hemólise do sangue de carneiro obtidos em placas e tubos foram comparados evidenciando um grande número de animais com venenos com alto poder hemolítico. Os valores não foram proporcionais quando os mesmos venenos foram examinados com hemáceas de homem. Neste caso os percentuais de hemólise foram mais baixos. Pode-se verificar que o poder hemolitico do veneno se relaciona com a concentração e pureza de suas frações. hemolitico.

Palavras-chaves: Veneno de cascavel. Poder

\section{ACKNOWLEDGMENTS}

We are grateful to Maria Aparecida Nonato Fernandes, Wander Cosme Ribeiro da Silva, Clementina Pereira de Oliveira Antonini and Rosângela Catarina Peral Mesquita for technical assistance.

\section{REFERENCES}

1. Conti MAB. Estrutura primária da cadeia B da Crotapotina. Tese de Doutorado. Faculdade Medicina de Ribeirão Preto, Universidade de São Paulo, 1986.

2. Gabilan NH. Estrutura primária da cadeia C da Crotapotina. Tese de Doutourado. Faculdade Medicina de Ribeirão Preto, Universidade de São Paulo, 1984.

3. Garcia-Lima E, Laure CJA. Study of bacterial contamination of rattlesnake venom. Revista da Sociedade Brasi- leira de Medicina Tropical 20: 19-21, 1987.

4. Goucher CR, Flowers HH. The chemical modification of neurogenic and proteolytic activities of venom and the use of EDTA to produce Agkistrodum piscivorus venom toxoid. Toxicon 2: 139-147, 1964.

5. Grotto L, Moroz C, DeVries A, Goldblum N. Isolation of vipera palestinae hemorrhagin and distinction between its hemorrhagic and proteolytic activities. Biochimica et Biophysica Acta 133: 356-362, 1967.

6. Habermann E. Bee and wasp venoms. Science 177: 314-322, 1972.

7. Houssay BA. Classification des actions de venins de serpents sur l'organismes animal. Comptes Rendus des Séances de la Société de Biologie 105: 308-310, 1930.

8. Huang SY, Perez JC. Comparative study on hemorrhagic and proteolytic activities of snake venoms. Toxicon 18: 421-426, 1980.

9. Kelen EMA, Rosenfeld G, Nudel F. Hemolytic activity of animal venoms. II. Variation in relation to erythrocyte species. Memórias do Instituto Butantan 30: 133-142, 1960-1961-1962.

10. Laure CJ. Estrutura primária da Crotamina. Tese de Livre-Docência. Faculdade Medicina de Ribeirão Preto, Universidade de São Paulo, 1975.

11. O'Connor R, Peck ML. Venoms of apidae. In: Bettini S. (ed.) Arthropod Venoms. Springer Verlag p. 613-618, 1978.

12 Omori-Satoh T. Antihemorrhagic factor as a proteinase inhibitor isolated from the serum of Trimeresurus flavoviridis. Biochimica et Byophysica Acta 495: 93-98, 1977.

13. Ownby CL, Geren CR Pathogenesis of hemorrhage induced by hemorrhagic proteinase IV from timber rattlesnake (Crotalus horridus horridus) venom. Toxicon 25: 517-526, 1987.

14. Rosenfeld G, Kelen EMA, Nudel F. Hemolytic activity of animal venoms. I. Classification in different types and activities. Memórias do Instituto Butantan 30: 117-132, 1960-1961-1962.

15. Tu AT, Toom PM, Ganthavorn S. Hemorrhagic and proteolytic activities of Thailand snake venoms. Biochemical Pharmacology 16: 2125-2130, 1967. 